\title{
ABOUT SIGNIFICANCE OF THE CONTROL PROBLEM OF ECOLOGICAL EFFICIENCY OF FUNCTIONING OF TECHNICAL OBJECTS
}

Voinova S.A., PhD, Associate Professor ${ }^{1}$

${ }^{1}$ Odessa National Academy of Food Technologies, Odessa

${ }^{1}$ E-mail: voinova_s@yahoo.com

${ }^{1}$ ORCID: 0000-0003-0203-0599

Copyright (C) 2014 by author and the journal "Automation technological and business - processes". This work is licensed under the Creative Commons Attribution International License (CC BY). http://creativecommons.org/licenses/by/4.0/
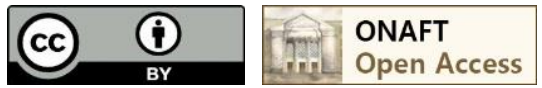

DOI: $10.15673 /$

\begin{abstract}
It's noted the current stress state of the natural environment due to the increasing harmful effects of the developing global production. It's indicated on the urgency to fully reduce the harmful effects of production. It's shown the control operation TO is highly efficient and productive means of improving the environmental performance of production. It's described the main features of management of ecology, created as well as existing worn out. It's shown the real possibilities of the use of management tools as a highly productive universal environmental funds.
\end{abstract}

Keywords

Ecological efficiency, functioning of technical object, environment, negative factors, control, progressive approach.

Introduction

Industrial activity of human works the intensive harmful influence upon a natural environment. It is shown by set of negative factors. The disastrous state of inorganic and live nature, is reflected in the international meetings documents in Kyoto and in Paris.

A stagnate period of progress of world production proceeding nowadays is characterized by strengthening of negative influence on environment. The given circumstance requires adequate strengthening of environmental activity.

\section{Statement of problem}

In any industry, a state of any technical object (TO), its technological properties and its level of technological efficiency (TE) functioning (further, in abbreviated form: «TO TE »), depend on quality of control of process of creation of object and process of its use.

Let's touch these two processes and approaches to the control statement of new TO.

At the traditional approach, after reception of the customer's application, in the market choose TO which was created as one of the standard solutions, and on the basic parameters suit to the circumstances of the customer, its future owner. Then they start to solve a problem of control chosen TO. It operatively is equiped by automatic control system; this system is adjusted on adjusting properties of chosen TO. It putting into action. That is, the control is formed only in the operational stage.

At the offered progressive approach to control of process of functioning TO, control is formed of three stages: strategic one, tactical one and operative one (Fig. 1,2) [1,2].

As a result of realization of this control model they receive a new TO which by technology, by design and by automatic control system properties precisely meets to customer's conditions. This TO has initial, maximum level TE. Thus, at the progressive approach realize an optimum version of control of level TE of new TO. New TO in this state is put into operation.

The comparative analysis of two approaches to control of TE of new TO testifies to conservatism of the traditional approach. 
New TO has maximum level TE, including a maximum level of its components: ecological one, economic one and technical one.

Put into operation TO while in using has continuous negative influence of process of physical wear. As a result, its ET level continuously decreases.

When current ET level decreases to minimally admissible level, the object finishes an expenditure of its resource of serviceability, reaches a limiting state and the object to be replaced to full updating - to replacement by new TO.

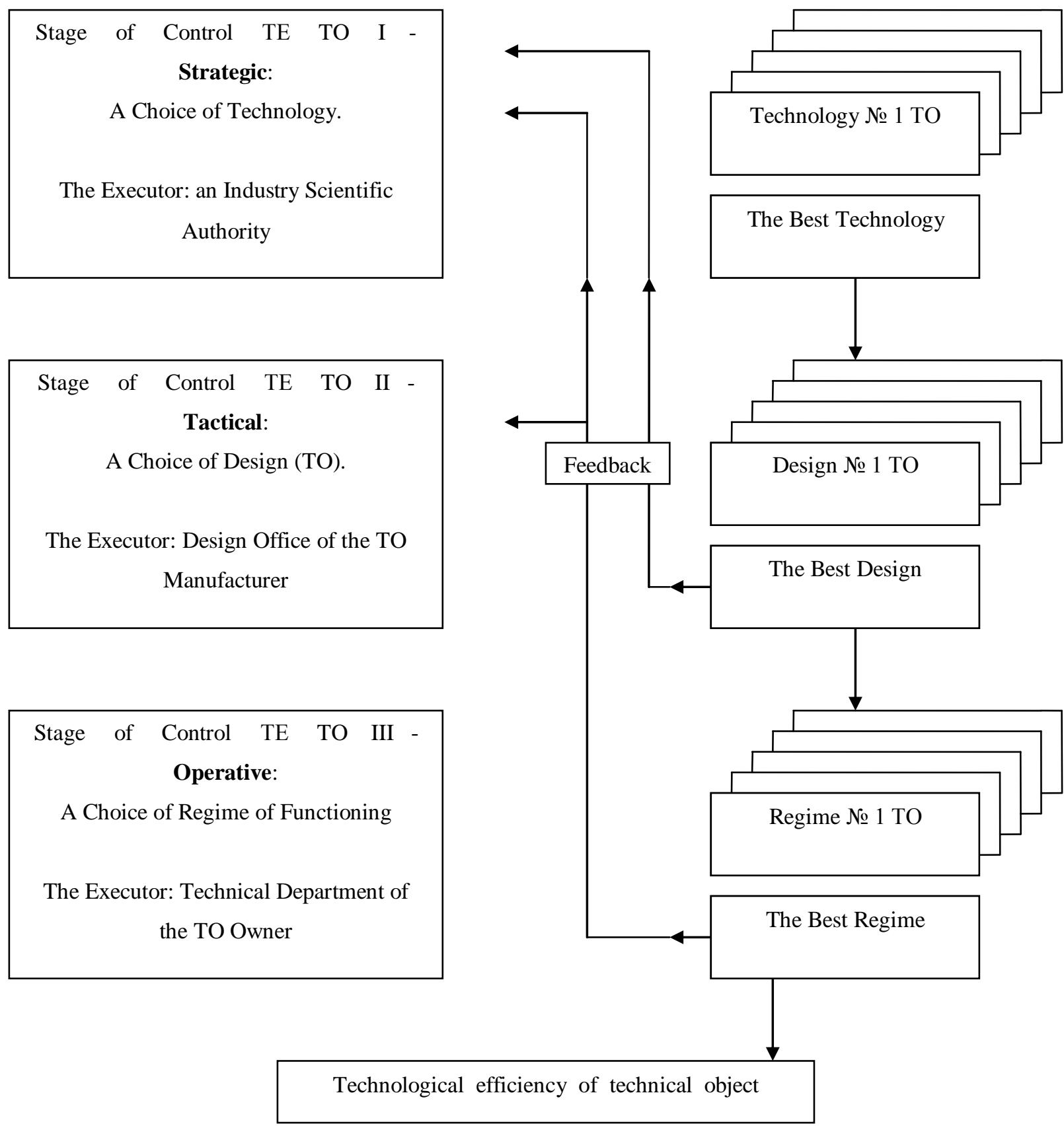

Fig. 1 - Structural - Logical Model of Formation of Technological Efficiency of TO Functioning

\section{Solutions to problems}

Started with the middle of 19-th century progress of world production by the industrial scenario uses achievements of science and techniques. However, alongside with it, it increases attendant sharply negative process of harmful influence on environment accrues. 
For normalization of a condition of environment, it is necessary to find and put into operation highly productive nature protection means. They should base also, on scientific and technical progress. These positions give to a science and techniques the status of driving force of world nature protection activity of mankind.

Level TE, including level of ecological efficiency, some TO is defined, as it is known, by quality of control process by its technological process.

Consequently, quality of control process by object defines its ecological compatibility. That is, improvement of quality of TO control is the nature protection tool. Giving to it of a target priority lifts its status up to a level of the concept [3].

At a present ecological situation in the world there are strong reasons to consider, that the main task of automatic control system (ACS) of functioning of any TO is control of its ecological efficiency level.

Thus, number of parameters of a current level of ecological efficiency TO maybe more than one.

Nature protection function of a science and techniques should be realized in two directions:

- Increase of ecological efficiency of carried out technological process of functioning TO,

- Increase of quality of control of ecological component of this process.

As is known, industrial objects, irrespective of their branch affiliation, character of production and productivity, represent complex systems of the interconnected elements. In them quality of technological process reflects some parameters. In similar cases ACS supports at the defined level some parameters. The main one among them, generally, should choose ecological efficiency.

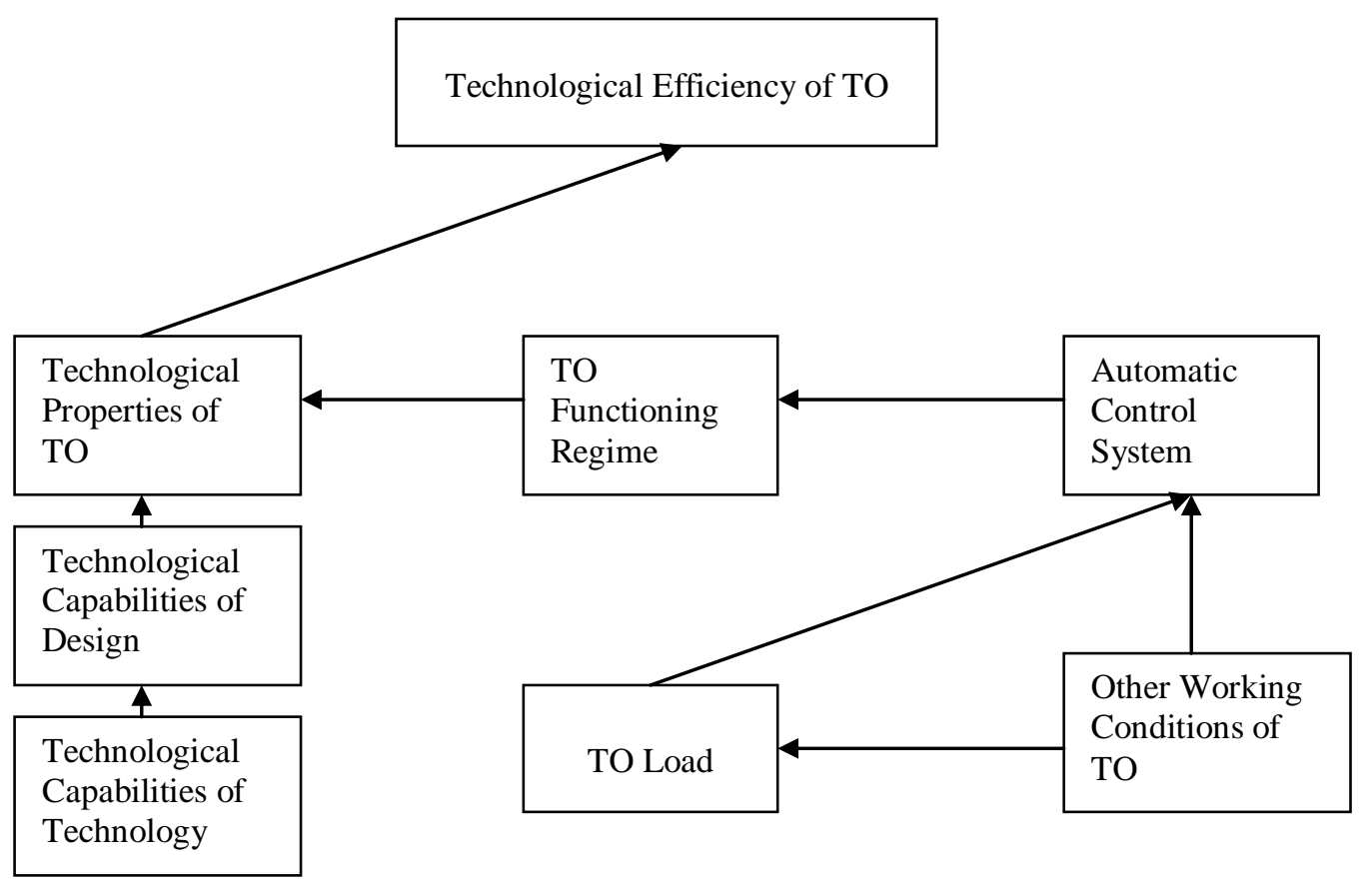

Fig. 2.- Structural - Logical Scheme of Interaction of Factors Which Affect the Technological Efficiency of TO Functioning

However, in some cases, for example, in power engineering, on vehicles, as the main parameter choose elements technical: reliability, a safety and ergonomics of work. They are controlled parameters, with them they appoint a resource TO.

The features of ecological efficiency control of life-expired TO, subjected to partial updating on the basis of modernization, reconstruction or technical re-equipment attract big attention.

In all cases, at creation new TO or at partial updating life-expired TO it is necessary to provide such proportion ecological, economic and technical parts of its resource at which the ecological resource would surpass others. In this case TO, fulfilled economic or technical resource, will have still a residual ecological resource, that is it will be still safe for environment. It conforms to the nature protection concept.

It is necessary to note the important circumstance: balance TO TE opens features of properties TO and conditions of control of formation its TE, in particular, formation its ecological efficiency [4].

In significant number of cases it is necessary to operate a current level of the several parameters, formed TO ecological efficiency. 
It is necessary to emphasize: control of formation TO ecological efficiency, control of a current level of formed it parameters should have complex system character [5].

Conclusions

1. The current position of OS requires acceptance of extraordinary measures for resolute decrease of level of harmful influence on it from industry.

2. Control of functioning TO is the productive tool defining a degree of its harmful influence on environment. Increase of quality of TO control reduces a level of this influence.

3. Main task of automatic control system by any TO is keeping of the set level its ecological efficiency.

4. The result of the control over a current level of ecological efficiency TO should be the main parameter of current level object' TE.

5. In some cases expediently to supervise and to control a current level of several ecological efficiency parameters.

6. In current conditions there was the ecological conditions, which force to apply a direct control of ecological efficiency level of the majority TO.

7. When you assign a resource TO is necessary to ensure the ratio of its components, with which the largest component is environmental one.

8. Then automatic control system of TO is an important means of ensuring a high level of its ecological efficiency.

Referenses

[1] Voinova S.O. Mozhlivosti upravlinnya efektivnistyu tehnichnih ob'ektyiv / Trudyi 15-y Mezhdunar. n.-t. konf. «Fizicheskie i kompyuternyie tehnologii», Harkov, 2-3 dekabrya 2009 g. - Harkov: HNPK «FED», 2009. - S. 93-95

[2] Voinova S.A. O podhode k upravleniyu tehnologicheskoy effektivnostyu sozdavaemyih tehnicheskih ob'ektov / Mizhnarodniy zhurnal «Avtomatizatsiya tehnologichnih i biznes-protsesiv», 2012, № 11, 12. - Odesa: ONAHT, 2012.- S. 26-28.

[3] Voinova S.O. Pro aktualnest upravlennya ekologechnoyu efektivnestyu tehnechnih ob'ektiv / «Energetika ta elektriflkatsiya», №1, 2012.- S. 64-67.

[4] Voinova S.A. Balans tehnologicheskoy effektivnosti funktsionirovaniya tehnicheskih ob'ektov v realnyih proizvodstvennyih usloviyah / Energetika ta elektriflkatsiya, 2015, №. 8.- S. $35-41$.

[5] Voinova S.O. Sistemniy pidhid do upravlinnya tehnologichnoyu efektivnistyu tehnichnih ob'ektiv / Fizicheskie i kompyuternyie tehnologii.- Trudyi 17-y Mezhdunarodnoy nauchno-tehnicheskoy konferentsii, 20-21 sentyabrya 2011g.- Harkov: HNPK «FED», 2011.- S.105-108.

\title{
DEVELOPMENT OF PRINCIPLES OF DCNET AND FLASH ENVIRONMENTS INTERACTION
}

\author{
A. V. Denisenko assistant ${ }^{1}$ \\ A. A. Gursky Ph.D. Art. Lecturer ${ }^{2}$
}

Copyright $(\mathcal{} 2014$ by author and the journal "Automation technological and business - processes".

This work is licensed under the Creative Commons Attribution International License (CC BY).

http://creativecommons.org/licenses/by/4.0/

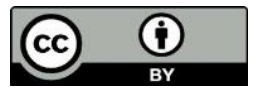

ONAFT

Open Access

DOI: $10.15673 /$

\section{Annotation}

The question of implementation of the interface between the DCNET and Flash media is examined. Usage of the interface-based DCNET environment allows to reduce time and material costs for the development $t$ and study of complicated technological system and to increase functional imaging capabilities compared to ActionScript.

Keywords

Discrete-continuous net, programming environment, xml, DCNET, Flash. 